\title{
Der III. Internationale Congress für Irrenpflege
}

findet unter dem Präsidium des Herm Hofrathes Professors Dr. Obersteiner vom 7. bis 11. October 1908 in Wien statt.

Beitrittserklärungen zu demselben, sowie Anmeldungen von Vorträgen wollen bis spätestens 1. Juli 1908 an den General-Sekretär Dr. Alexander Pilcz in Wien, IX., Lazarethgasse 14 eingeschickt werden, welcher auch nähere Auskïnfte zu ertheilen bereit ist.

Das genauere Programm wird seiner Zeit verlautbart werden.

Das vorbereitende Comité für den III. Internationalen Congress für lrrenpflege in Wien 1908.

Der Präsident:

Hofrath Professor Dr. Obersteiner.

Der General-Sekretär:

Privat-Docent Dr. Alexander Pilcz. 